\title{
Assessment of Resistance of four Nitrogen-Fixing Bacteria to Glyphosate
}

\author{
Mohamed Maldani, Btissam Ben Messaoud, Laila Nassiri, and Jamal Ibijbijen*
}

Environment and Soil Microbiology Unit, Faculty of Sciences, Moulay Ismail University, B. P. 11201 Zitoune, Meknes, Morocco.

Received: May 21, 2018 / Accepted: August 4, 2018

\begin{abstract}
The presence of residual pesticides in the soil affect the microbial Communities, as well the continuous use of pesticides exacerbates this problem. Glyphosate is one of the most used herbicides in the world. Up to date several studies have evaluated the tolerance and resistance of bacteria to glyphosate. Nitrogen-fixing bacteria play an important role in soil fertility; thus, the alteration of these bacterial communities decrease soil fertility. The objective of this study was to evaluate the effect of glyphosate application on four bacterial strains Pantoea agglomerans, Rhizobium nepotum, Rhizobium radiobacter, and Rhizobium tibeticum. Glyphosate was applied as the sole source of carbon at the rate $(0$ $\mathrm{g} / \mathrm{l}, 0.5 \mathrm{~g} / \mathrm{l}, 1 \mathrm{~g} / \mathrm{l}, 3 \mathrm{~g} / \mathrm{l}, \mathbf{6 g} / \mathrm{l}$ and $12 \mathrm{~g} / \mathrm{l})$ with two methods. Microbial growth was measured by the Colony Forming Units (CFUs /ml) method. Comparing with the control, our results showed that the growth of the four strains decreased by increasing the concentration of glyphosate. The four strains have shown resistance to glyphosate in the direct enrichment compared to the continued enrichment method. Comparing strains with each other, Rhizobium radiobacter is the most resistant strain to glyphosate.
\end{abstract}

Keywords: Glyphosate; Pesticide; Nitrogen-fixing bacteria; Tolerance.

\footnotetext{
* Corresponding author: j.ibijbijen@fs.umi.ac.ma
}

\section{Introduction}

Glyphosate [N-(phosphonomethyl) glycine], the active ingredient of the herbicide Roundup, is a systemic, post-emergent, broad-spectrum herbicide, it is an inhibitor of aromatic amino acid synthesis (Calvet et al., 2005). Is Introduced in agriculture in the 1970s (Munira et al., 2016). The high efficiency in protecting crops against weeds has enabled the glyphosate to become the most widely used herbicide in the world (Chlopecka et al., 2017), knowing that it occupied a quarter of the world's herbicide sales (Munira et al., 2016).

Glyphosate is foliarly applied. However, an important quantity of the herbicide may reach the soil. Moreover, it will be leaching to groundwater. Thereby, the study of interaction microorganisms/glyphosate in soil is very important. The soil is one of the largest reserves of the planet biodiversity. The nitrogen-fixing and phosphate-solubilizing bacteria are among the important bacteria in the soil, they play an important role in the nitrogen and phosphorus availability in the soil, and consequently on soil fertility. The bacterial nitrogen fixation phenomenon is an alternative to the high use of chemical fertilizers (Bhattacharjee et al., 2008).

Previous studies have indicated that the glyphosate may modify natural ecosystem by affecting different components of the soil microbial community (Carlise and Trevors, 1988; Ermakova et al., 2010). Glyphosate can affect the fungi and bacteria in soil (Imparato et al., 2015). Whereas, numerous studies have shown microorganisms can degrade that glyphosate. Several potential glyphosate degrading microorganisms have been isolated from organophosphates contaminated soils (Shushkova et al., 2010) such as Enterobacter cloacae (Kryuchkova et al., 2014), Geobacillus caldoxylosilyticus (Obojska et al., 2002), Pseudomonas spp. (Dick and Quinn, 1995), Rhizobium sp. and 
Agrobacterium sp. (Liu et al., 1991).

Due to its great impacts mainly on the ecology and the health, and based on previous studies in this field, we carried out this study whose objectives are to evaluate the glyphosate tolerance using two enrichment methods of four nitrogen-fixing bacteria, which were isolated from the nodules of a legume ( $B i$ tuminaria bituminosa). As well to assess the effects of glyphosate concentration on the growth of these four bacterial strains, using glyphosate as a sole source of carbon.

\section{Materials and Methods}

\section{Chemicals Used}

The glyphosate used was a commercial RoundUp ${ }^{\circledR}$ (containing $360 \mathrm{~g}$ active ingredient/L of glyphosate, Monsanto) purchased from a local dealer's store in Tanger, Morocco. All the other chemicals were characterized by a high purity commercially available.

To evaluate the tolerance or resistance of our bacterial strains to the glyphosate we have used it as a sole source of carbon and phosphorus, we used a mineral salt medium without carbon source (MSMC). The composition of MSMC in grams per liter of distilled water $\mathrm{pH}$ (7.0-7.2). was KH2PO4 (1.5), Na2HPO4 $12 \mathrm{H} 2 \mathrm{O}$ (1.5), NH4SO4 (2), MgSO4 7H2O (0.2), CaCl2 (0.01), FeSO4 and 7H2O (0.001). The media was supplemented with glyphosate sterilized by filtration $(0.2 \mu \mathrm{m}$ filter). Mineral salt medium (MSM) with glucose as carbon source was used as control, the composition of MSM Control in grams per liter of distilled water $\mathrm{pH}$ (7.0-7.2) was $\mathrm{C} 6 \mathrm{H} 12 \mathrm{O} 6$ (10). KH2PO4 (1.5), Na2HPO4 12H2O (1.5), NH4SO4 (2), MgSO4 7H2O $(0.2), \mathrm{CaCl} 2(0.01)$ and $\mathrm{FeSO} 47 \mathrm{H} 2 \mathrm{O}(0.001)$.

\section{Bacterial Strains}

Four bacterial strains were selected to test their tolerance or resistance to glyphosate. These strains were originally isolated from nodules root of legume "Bituminaria bituminosa" cultivated in the experimental station of the faculty of sciences, Moulay Ismail University, Meknes. The selection of strains was based on their ability to fix nitrogen. The selected strains are Pantoea agglomerans, Rhizobium nepotum, Rhizobium radiobacter and Rhizobium tibeticum.

\section{Preparation of Inoculum}

Inocula were prepared for the four strains by culturing the strains in $50 \mathrm{ml}$ of nutrient medium for three days at $30^{\circ} \mathrm{C}$ under stirring conditions $(150 \mathrm{rpm})$ until growth reached late exponential phase. Cells were harvested by centrifugation at $4,600 \mathrm{~g}$ for $5 \mathrm{~min}$, washed with sterile saline solution $0.9 \%$ and were resuspended in 0.5 McFarland standard (Optical density of 0.108 at $625 \mathrm{~nm}$ ), this suspension was used as inoculum.

\section{Treatments of Used Bacteria}

\section{Continuous Enrichment}

Glyphosate tolerance experiments were performed in flasks $(250 \mathrm{ml})$ containing $100 \mathrm{~mL}$ of sterile MSMC with $0.5 \mathrm{~g} / 1$ of glyphosate. $2 \mathrm{ml}$ of each inoculum was added to a sterilized flask and for each sstrain, three replicates were done, then all the flasks were incubated on a rotary shaker at $150 \mathrm{rpm}$ for 7 days at $30^{\circ} \mathrm{C}$. After 7 days $5 \mathrm{~mL}$ of each flask were transferred to fresh MSMC containing $1 \mathrm{~g} / \mathrm{L}$ glyphosate and incubated for 7 days. Three additional and successive transfers were made into media successively containing 3, 6 and $12 \mathrm{~g} / \mathrm{L}$ of glyphosate.

\section{Direct Enrichment}

Two (2) $\mathrm{ml}$ of each inoculum were added in flasks $(250 \mathrm{ml})$ containing $100 \mathrm{ml}$ of sterile MSMC with $0.5 \mathrm{~g} / 1,1 \mathrm{~g} / \mathrm{l}, 3 \mathrm{~g} / \mathrm{l}, 6 \mathrm{~g} / \mathrm{l}$ and $12 \mathrm{~g} / 1$ of glyphosate in each one. Triplicate culture were incubated on a rotary shaker at $150 \mathrm{rpm}$ for 7 days at $30^{\circ} \mathrm{C}$.

\section{Enumeration of Bacterial Strains}

The bacteria were counted for each concentration $(0.5,1,3$, $6,12 \mathrm{~g} / \mathrm{l})$ including the control, after 7 days of incubation; $1 \mathrm{ml}$ of each sample was used to provide a series of dilutions (10-1, $10-2,10-3,10-4$ and 10-5). Moreover, $0.1 \mathrm{ml}$ of each dilution was added to the plates containing the Plate Count Agar (PCA) medium, which its composition in gram per liter of distilled water, $\mathrm{pH}(7.0,7.2)$ is: Tryptone (5), yeast extract $(2.5)$, glucose (1), Agar (15). The plates were incubated at $28 \pm 2{ }^{\circ} \mathrm{C}$, for $72 \mathrm{~h}$.

\section{Statistical Data Analysis}

All variables were analyzed by ANOVA (analysis of variance) and significant differences among treatments were determined using Tukey post-hoc test. Differences between treatments were considered statistically significant at $\mathrm{p}<0.05$. IBM SPSS statistics 20 was used for all above statistical analysis.

\section{Results and Discussion}

In order to assess the tolerance of bacterial strains (Pantoea agglomerans, Rhizobium nepotum, Rhizobium radiobacter, and Rhizobium tibeticum) to glyphosate, we evaluated the growth of each strain while increasing glyphosate concentration with two methods: continuous and direct enrichment.

Statistically, and comparing with the control, significant differences $(p<0.05)$ were observed for the four strains using both methods: direct enrichment (Figure 1) and continuous enrichment (Figure 2). Bacterial load decreased highly while increasing glyphosate concentration in continuous enrichment, whereas in direct enrichment the bacteria showed a tolerance to glyphosate except Rhizobium tibeticum strain. Moreover, comparing the strains with each other in the continuous enrichment, no resistance was observed in the concentrations greater than or equal to $1 \mathrm{~g} / \mathrm{l}$ of glyphosate, which is the recommended 


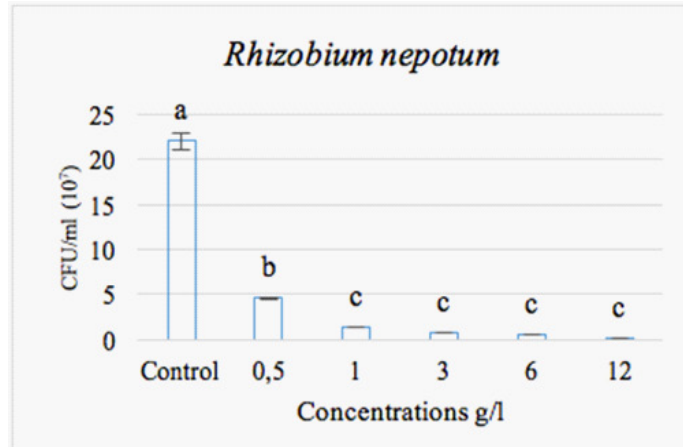

\section{Rhizobium radiobacter}

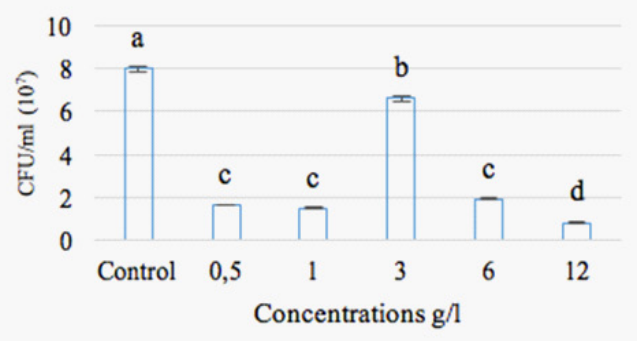

\section{Pantoea agglomerans}

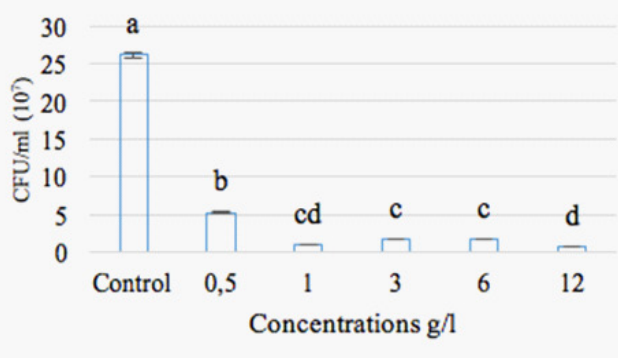

Rhizobium tibeticum

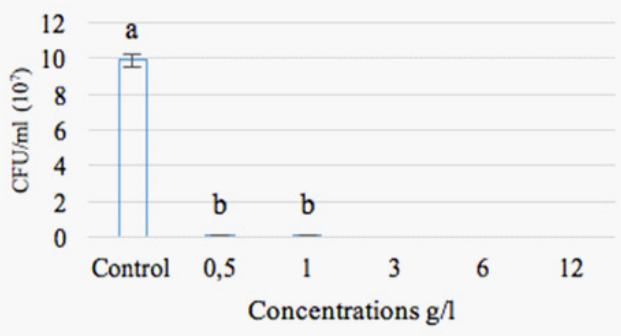

Each bar represents the mean average $(n=3)$, the error bars represent standard deviations. Means followed by different letters are significantly different at $\mathrm{p}<0.05$ according to Tukey test.

Figure 1. Effect of increasing glyphosate concentration on the growth of Bacterial strains in direct enrichment.

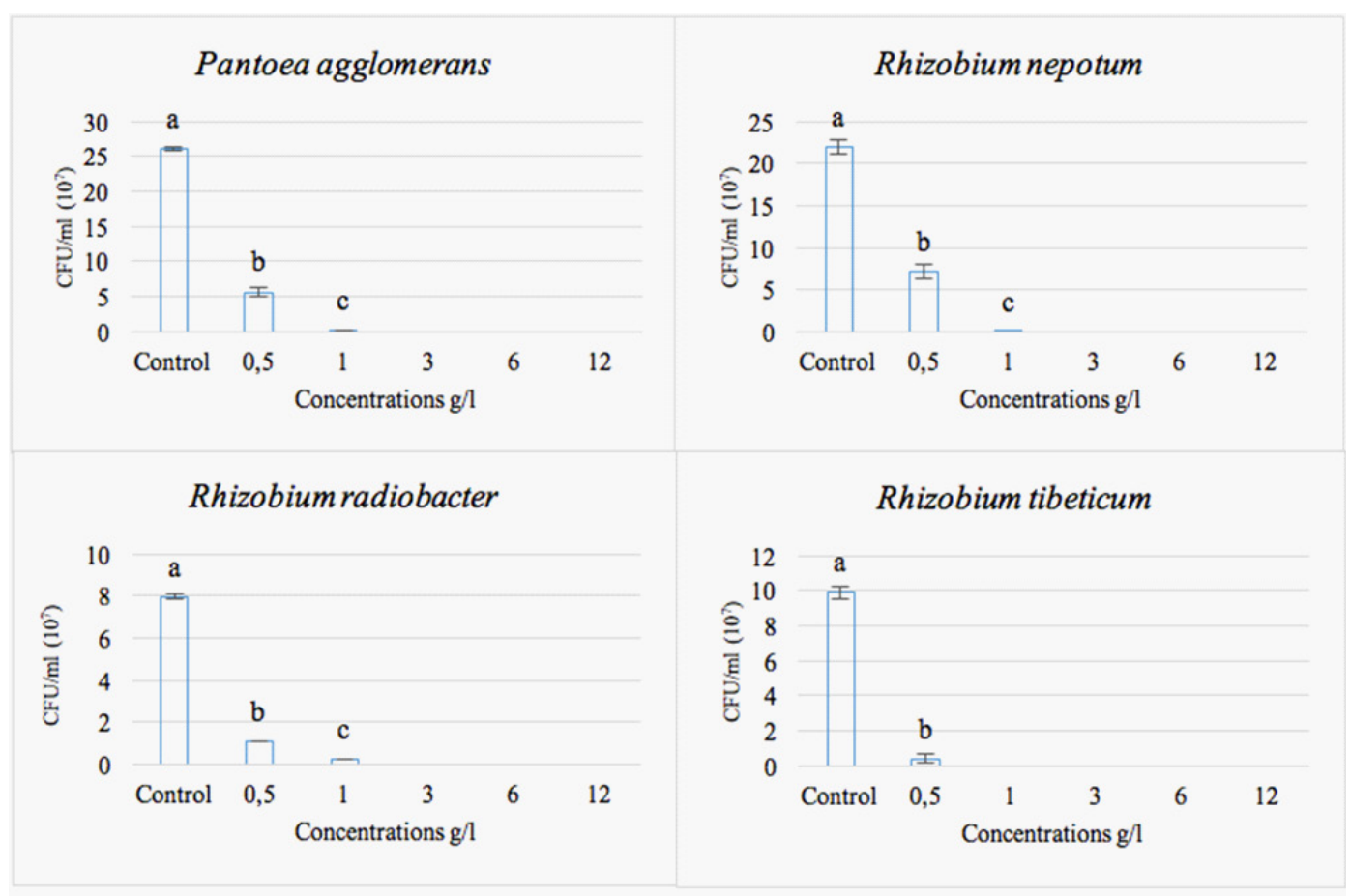

Each bar represents the mean average $(n=3)$, the error bars represent standard deviations. Mean followed by different letters are significantly different at $\mathrm{p}<0.05$ according to Tukey test.

Figure 2. Effect of increasing glyphosate concentration on the growth of Bacterial strains in continuous enrichment. 


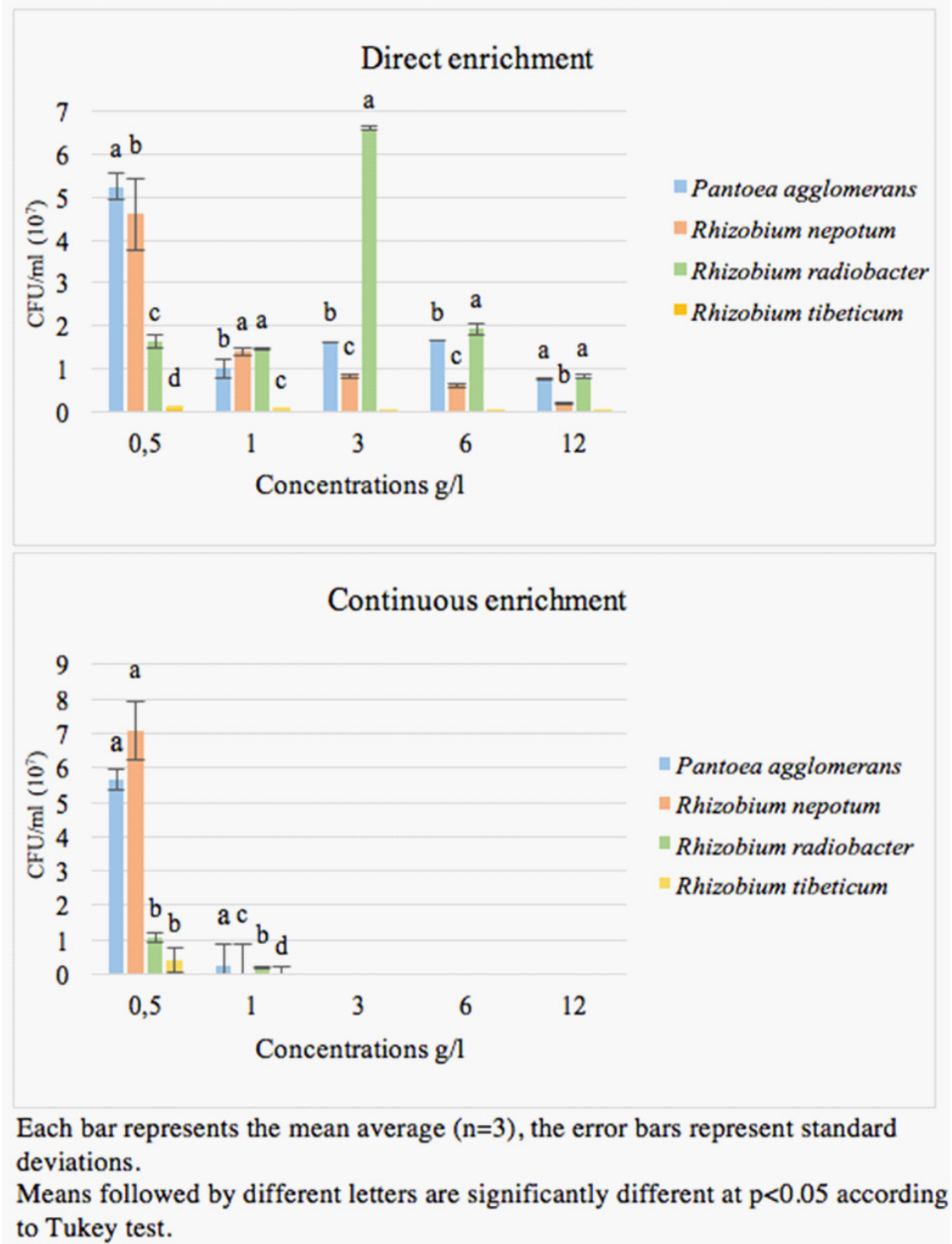

Figure 3. Comparison of glyphosate effect on four strains in two methods.

dose in Morocco (Figure 3). Whereas in direct enrichment the behavior of the four strains was different (Figure 3), Rhizobium radiobacter and Pantoea agglomerans strains tolerated concentrations up to $12 \mathrm{~g} / 1$ (Figure 1), while Rhizobium nepotum tolerated concentrations up to $6 \mathrm{~g} / 1$ (Figure 1). Whilst Rhizobium tibeticum had no activity in all treatment (Figure 1). The microorganism's physiology and genetic's play a key role on their tolerance or resistance to pesticides. Generally, the microorganisms resistant to pesticide have a great potential to break the pesticides into simple products, which may be used by them as nutrient sources, such as carbon and phosphorus (Cassigneul et al., 2016; Myresiotis et al., 2012; Bellinaso et al., 2003). According to the results of (Wijekoon et al., 2018) which have shown that Pseudomonas sp. and Bacillus sp. are able to degrade glyphosate even at its high concentrations, these results are consistent with ours mainly for Rhizobium radiobacter and Pantoea agglomerans in direct enrichment and without carbon in the medium. As so, it can be suggested that these two strains used glyphosate as a source of carbon, while the be- havior of these two strains was different in continuous enrichment. This result can be explained by the accumulation of the glyphosate, which make the medium toxic. Thus, several studies have reported the eco-toxicity of glyphosate on specific soil microorganisms (Allegrini et al., 2015; Sihtmäe et al., 2013). On the other hand, according to the study made by (Ahemad et al., 2012), the glyphosate affects negatively the growth of Mesorhizobium strain MRC4, these results are consistent with those obtained for Rhizobium tibeticum strain, as well as those of (Ermakova et al., 2010) who claimed that none of the two Achromobacter sp. and Ochrobactrum anthropi bacteria could degraded glyphosate.

Overall, the effect of glyphosate on the bacterial community is different from one bacterial species to another. Some strains are able to resist or tolerate glyphosate and use its metabolites as a source of nutrients and/or energy, whereas the glyphosate may be toxic for other strains; these findings was proved by several studies (Sihtmäe et al., 2013; Araujo et al., 2003; Tsui et al., 2003). 
Our results showed that the continuous use of glyphosate affect nitrogen-fixing bacteria which play an important role in soil fertility. however, more research is needed in the field to better understand the effect of glyphosate on soil fertility. Therefore, perspective research projects can focus on the genetics of the soil microbial community and its behavior towards glyphosate application.

\section{Acknowledgments}

Our special thanks to Environment \& Soil Microbiology Unit, Department of Biology, Faculty of Sciences, Moulay Ismail University, Meknes, Morocco and all those who helped us to accomplish this work.

\section{References}

Ahemad M, and MS Khan (2012) Ecological assessment of biotoxicity of pesticides towards plant growth promoting activities of pea (Pisum sativum)-specific Rhizobium sp. strain MRP1. Emir J Food Agric 24 (4): 334-343.

Allegrini M, MC Zabaloy, and EV Gómez (2015) Ecotoxicological assessment of soil microbial community tolerance to glyphosate. Sci Total Environ 533: 60-68.

Araújo ASF, RTR Monteiro, and RB Abarkeli (2003) Effect of glyphosate on the microbial activity of two Brazilian soils. Chemosphere 52 (5): 799-804.

Bellinaso MDL, CW Greer, MC Peralba, JAP Henriques and CC Gaylarde (2003) Biodegradation of the herbicide trifluralin by bacteria isolated from soil. FEMS Microbiol Ecol 43: 191-194.

Bhattacharjee RB, A Singh, and SN Mukhopadhyay (2008) Use of nitrogen-fixing bacteria as biofertilizer for non-legumes: prospects and challenges. Appl Microbiol Biotechnol 80(2) : 199-209.

Calvet R, E Barriuso, P Benoit, C Bedos, MP Charnay, and Y Coquet (2005) Les pesticides dans le sol: Conséquences agronomiques et environnementales. Editions France Agricole, Paris.

Carlisle SM, and JT Trevors (1988) Glyphosate in the environment. Water Air and Soil Pollution 39(3):409-420.

Cassigneul A, P Benoit, V Bergheaud, V Dumeny, V Etiévant, V Goubard, A Maylin, E Justes, and L Alletto (2016) Fate of glyphosate and degradates in cover crop residues and underlying soil: A laboratory study. Sciof Total Enviro 545-546:582-590.

Chłopecka M, M Mendel, N Dziekan , and W Karlik (2017) The effect of glyphosate-based herbicide Roundup and its co-formulant, POEA, on the motoric activity of rat intestine - In vitro study. Environ Toxicol Pharmacolo 49:156-162.
Dick RE, and JP Quinn (1995) Glyphosate-degrading isolates from environmental samples: occurrence and pathways of degradation. Appl Microbiol Biotechnol 43(3):545-50.

Ermakova IT, NI Kiseleva, T Shushkova, M Zharikov, GA Zharikov, and AA Leontievsky (2010) Bioremediation of glyphosate-contaminated soils. Appl Microbiol Biotechnol 88(2): 585-94.

Imparato V, SS Santos, A Johansen, S Geisen, and A Winding (2016) Stimulation of bacteria and protists in rhizosphere of glyphosatetreated barley. Applied Soil Ecology 98:47-55.

Kryuchkova YV, GL Burygin, NE Gogoleva, YV Gogolev, MP Chernyshova, OE Makarov, EE Fedorov, and OV Turkovskaya (2014) Isolation and characterization of a glyphosate-degrading rhizosphere strain, Enterobacter cloacae K7. Microbiol Res 169:99-105.

Liu CM, P McLean, C Sookdeo, and F Cannon (1991) Degradation of the herbicide glyphosate by members of the family Rhizobiaceae. Applied Environ Microbiol 57(6):1799-1804.

Lynch J, A Benedetti, H Insam, M Nuti, K Smalla, and V Torsvik (2004) Microbial diversity in soil: ecological theories, the contribution of molecular techniques and the impact of transgenic plants and transgenic microorganisms. Biol Fertil Soils 40:363-385.

Muniraa S, A Farenhorst, D Flaten, and C Grant (2016) Phosphate fertilizer impacts on glyphosate sorption by soil. Chemosphere 153: 471-477.

Myresiotis CK, Z Vryzas, and E Papadopoulou-Mourkidou (2012) Biodegradation of soil-applied pesticides by selected strains of plant growth-promoting rhizobacteria (PGPR) and their effects on bacterial growth. Biodegradation 23(2):297-310.

Obojska A, NG Ternan, B Lejczak, P Kafarski, and G McMullan (2002) Organophosphonate utilization by the thermophile Geobacillus caldoxylosilyticus T20. Appl Environ Microbiol 68(4):20814.

Sharifi Y, AA Pourbabaei, A Javadi, MH Abdolmohammadi, M Saffari, and A Morovvati (2015) Biodegradation of glyphosate herbicide by Salinicoccus spp isolated from Qom Hoze-soltan lake, Iran. Environ health eng manag $\mathrm{J} 2(1)$ : 31-36.

Shushkova T, I Ermakova, and A Leontievsky (2010) Glyphosate bioavailability in soil. Biodegradation 21(3): 403-410.

Sihtmäe M, I Blinova, K Künnis-Beres, L Kanarbik, M Heinlaan, and A Kahru (2013) Ecotoxicological effects of different glyphosate formulations. Appl Soil Ecol 72:215-224.

Tsui MTK, and LM Chu (2003) Aquatic toxicity of glyphosate-based formulations: comparison between different organisms and the effects of environmental factors. Chemosphere 52:1189-1197.

Wijekoon WMNDK and PN Yapa (2018) Assessment of plant growth promoting rhizobacteria (PGPR) on potential biodegradation of glyphosate in contaminated soil and aquifers. Groundwater for Sustainable Development. https://doi.org/10.1016/j.gsd.2018.02.001. 